\title{
Tactics for Xinjiang Tourism Industrial Belt Based on Performance Evaluation
}

\author{
Xin Qian ${ }^{1}$, Yuping $X u^{2} \mathbb{D}$, Xuehui Mei $^{2, *(D)}$ and Xia Xie ${ }^{3} \mathbb{D}$ \\ 1 School of Economics and Management, Chinese Academy of Sciences, Beijing 100864, China; \\ qianxin3@sina.com \\ 2 College of Mathematics and System Science, Xinjiang University, Urumqi 830046, China; \\ yuping_xu163@163.com \\ 3 College of Tourism, Xinjiang University, Urumqi 830046, China; xiexia@xju.edu.cn \\ * Correspondence: meixuehui163@163.com
}

Citation: Qian, X.; Xu, Y.; Mei, X.; Xie, $X$. Tactics for Xinjiang Tourism Industrial Belt Based on Performance Evaluation. Sustainability 2021, 13, 12473. https://doi.org/10.3390/ su132212473

Academic Editor: Yoshiki Shimomura

Received: 5 October 2021

Accepted: 8 November 2021

Published: 11 November 2021

Publisher's Note: MDPI stays neutral with regard to jurisdictional claims in published maps and institutional affiliations.

Copyright: (c) 2021 by the authors. Licensee MDPI, Basel, Switzerland. This article is an open access article distributed under the terms and conditions of the Creative Commons Attribution (CC BY) license (https:// creativecommons.org/licenses/by/ $4.0 /)$.

\begin{abstract}
In this paper, some tactics are considered in Xinjiang tourism industrial belt based on performance evaluation. First, we applied the Balanced Scorecard (BSC) to establish an evaluation system for Xinjiang tourism development in four dimensions: tourism performance, resource utilization, basic supporting capacity, and market attention. Second, the performance of tourism development in 14 Prefectures was evaluated using the Analytic Hierarchy Process (AHP) in 2018. Third, because the Prefectures were divided into four tourism industrial belts, a discussion was conducted to identify and understand the difference among them and their corresponding influence on regional tourism development using the Theil index and Entropy method. The result shows that (1) In all dimensions, the differences within each industrial belt were greater than those between industrial belts. (2) The tourism industrial belts displayed a differentiation phenomenon, in the dimension of significant difference being distinct for different belts. Finally (3), it is found that the resource utilization of all belts is significantly different.
\end{abstract}

Keywords: tourism industrial belt; performance evaluation; balanced scorecard; analytic hierarchy process; Theil index; entropy method

\section{Introduction}

In recent years, under the guidance of China's "One Belt and One Road" and the "13th Five-year Plan", the tourism industry played a significant role in stimulating revenue, expanding domestic demand, promoting employment, and spurring the rapid growth of relevant industries. The Belt and Road Initiative fully embodies the borderless nature of infrastructure development, and it also promotes the development of tourism in Xinjiang [1]. It is an important driving force for economic development, and it has an increasingly strong influence on national economic growth. With the promotion of the "Prospering Xinjiang through tourism" strategy, the overall development scale of the Xinjiang tourism industry continues to expand, and the investment for the tourism industry in various regions continues to increase. Xinjiang's tourism industry shows a sustained and rapid growth trend, becoming a sunrise industry with a strong driving capacity and great development potential.

Tourism to Xinjiang cannot be separated from politics, and state policies influence Chinese travelers' views on their experience [2]. According to the 2018 Xinjiang Uygur Autonomous Region Statistical Bulletin on National Economic and Social Development, the region received 150.2489 million tourists, with an increase of $40.1 \%$ over the previous year. Meanwhile, the aggregate tourism consumption was 257,971 billion yuan, with an increase of $41.6 \%$. The data shows that the overall development of the Xinjiang tourism industry tends to go well. However, from the perspective of Xinjiang 14 Prefectures, significant differences in the development of the tourism industry still exist. How to 
evaluate the development of regional tourism and adequately measure the effectiveness of its development has become the major focus of governments at all levels.

The conditions of economic development and resource endowment differ depending on the region. Therefore, different evaluation systems and methods will be required to assess the development of their tourism industry. From the existing research, various comprehensive systems for evaluating tourism development grounded in the local conditions have been built. Wu et al. (2012) established an evaluation system for water conservancy ecotourism development potential using four aspects: resource status, market response, development conditions, and environmental impact [3]. Through the principal component analysis, Wu et al. (2014) determined the index weight and established the evaluation system. It included measuring (i) the carrying capacity of ice and (ii) snow tourism resources, making the evaluation score more scientific and reasonable [4]. Li et al. (2016) took into account three dimensions of natural ecological environment, human social environment and industrial economic environment, and constructed the environmental health evaluation system of leisure agricultural tourism development [5]. Notably, the social dimension was rarely seen in previous studies. Based on smart tourism, Huang et al. (2017) determined the evaluation dimensions of tourism economic development [6], tourism science and technology innovation, tourism development potential, tourism environment support and tourism development logistic support.

Following these studies, the evaluation model of urban tourism competitiveness was created. Butowski (2018) constructed a tourism attraction evaluation system from the dimensions of climate and weather conditions [7], natural scenery, cultural attractions, and cultural environment. Therefore, it could be used to measure the tourism attraction of the destination from a natural and cultural standpoint. Ling (2019) built the development performance evaluation system based on the economic, social, and ecological benefits [8]. At the same time, to evaluate the development of leisure agriculture, Ling built the development potential evaluation system based on the resource conditions and management level. Gao et al. (2020) constructed the performance evaluation system of island tourism using the hinterland effect, economic effect, equity effect, and ecological effect, then analyzed the driving factors of performance evaluation [9]. There are also a few studies evaluating the development of the tourism industry from the perspective of tourists, such as that of Grilli et al. (2020), which offered an empirical analysis from the perspective of tourists to discuss the sustainable development of tourism [10]. Liu and Zhang's (2020) evaluation framework included four subsystems: tourism environmental resources, society, economy, and development support [11]. Tourist satisfaction is added into the social subsystem and enriches the entire evaluation.

With the rapid development of information and communication technology in recent years, tourists' behavior and consumption patterns have changed significantly. The driving force of tourism is now moving away from the supply side (tourism sites) to the demand side (the tourists), thus considering the needs and concerns of tourists is essential for improving the regional and overall development of tourism. The existing research on the construction of the tourism development evaluation system primarily focuses on the supply side, while tourists are rarely included. In the performance evaluation, a balanced scorecard is generally applied as a performance measurement tool in hotels, scenic locations, and urban tourism development quality. The balanced scorecard was first proposed by Kaplan and Norton in 1992 [12]. For the past few years, (Ma and Hou, 2016; Liang and Liu, 2018) introduced the balanced scorecard into performance evaluation as the basis of dimension selection [13,14]. In 2019 Zhou established a quality evaluation system of urban tourism development according to a balanced scorecard [15]. Furthermore, Wang et al. (2020) designed the performance evaluation framework of smart tourism in scenic spots based on the balanced scorecard [16]. Meng et al. (2020) established the evaluation model of influence degree [17], and in doing so, broadened the application field of the balanced scorecard. 
The research above provided a theoretical and methodological reference for the construction of tourism development. However, the research on implementing the balanced scorecard to build a comprehensive evaluation system of tourism development is relatively insufficient. As one of the strategic pillar industries in Xinjiang development, tourism is planned strategically and proactively. In this paper, we applied a balanced scorecard to construct a comprehensive regional development evaluation system based on four dimensions. To evaluate the survival and development ability of the tourism industry, the dimension of tourism performance was selected. We also selected the dimension of tourism resource utilization to fully embody the degree of congenital tourism resource utilization and indicate business capability of the tourism industry. Furthermore, to comprehensively compare the satisfaction degree of the tourism industry to customers' basic needs, the dimension of tourism's basic supporting capacity was selected. Finally, the dimension of market attraction was added to show the ability of the tourism industry to attract customers and improve itself. In combining these four dimensions, the evaluation system can comprehensively assess the past, present, and future value realization ability of the tourism industry.

The division of the tourism industry belt is the basis in analyzing the differences between industries. It has become a theoretical basis since the "point-axis system" theoretical model was put forward in 1984. Domestic research on tourism has been carried out with the requirements of tourism development planning. (Ma and Wang, 2009; Gao and Chen, 2009) studied the development of the leisure tourism industry area around Beijing [18,19], Tianjin, and Hebei Province, and put forward some suggestions for its development. Drawing on the related theories of industrial competitiveness, Wen and Yang (2012) constructed the system for evaluating tourism competitiveness which included industrial strength, industrial competitive potential, and tourism environmental protection [20]. The hierarchical clustering method was also used to evaluate the cities comprehensively. According to the clustering, the tourism industry was divided to build a win-win competition and cooperation mechanism. Using the fractal theory of aggregation dimension and correlation dimension, Feng (2014) made a quantitative analysis of the spatial distribution equilibrium of the core scenic spots [21], looking mainly at the tourism industry around Junggar (the focus of the "12th Five-year Plan" of Xinjiang tourism industry). However, the literature and research on the tourism industry belt are scares. As an important part of tourism development planning, the research of industrial belt is a vital content of industrial spatial layout, and it is also a vital carrier of regional tourism cooperation. Thus, the tourism industry must seek to establish a development system centered around consumer demand, give full access to the diversified and differentiated supply of tourism products, and strengthen regional cooperation. The study on the tourism industry belt also helps provide a theoretical basis and practical guidance for the regional development planning of the tourism industry.

Theil index can be used to decompose the differences of tourism development and fractionize them into the differences within one belt and between industry's other belts and make a quantitative analysis of regional differences. The Theil index has been widely used by researchers in the analysis of economic differences. Gao (2012) introduced the Theil index to study the changes in China's regional economic gap in 31 provinces from 1978 to 2009 [22]. Chen and Zhang (2020) used the Theil index along with other methods to study and analyze the imbalance of China's regional economic development as well as its influencing factors [23]. Zhang and Wen (2020) took the real economy as the research object [24], then applied quantitative methods such as Moran's I index, Theil index, and kernel density estimation to study the spatial correlation, regional differences, and dynamic evolution of the real economy. Using the total tourism income of the Huaihe River ecological economic belt from 2007 to 2018, Yan and Cui (2020) applied the Theil index and other indicators to study the spatial-temporal differentiation and convergence of the tourism economy in Huaihe River ecological economic belt [25]. The result showed that the overall tourism economy of the Huaihe River Basin tended to converge, and the imbalance of the tourism 
economy had been improved. The review of the existing studies indicates that the use of the Theil index to analyze the multidimensional tourism development differences between industrial belts is not a common practice. Most studies evaluated the index system of a city alone, rarely dividing it into industrial areas according to the actual divisions within the city, and thereby ignored the relationship between regional competition and cooperation.

In this study, we applied a balanced scorecard and took the region as a management unit. Based on the concept of the regional tourism industry's past, present, and future value realization ability, we constructed the tourism industry development performance evaluation system. Employing the analytic hierarchy process, Theil index, and entropy method, we evaluated the tourism development performance of 14 Prefectures in Xinjiang in 2018 and analyzed the development of tourism in four industrial belts. We made improvements in the following three aspects compared with the previous research: First, taking the regional tourism industry as a performance unit, we established a development performance evaluation system with indexes based on four dimensions of tourism performance, tourism resource utilization, tourism basic supporting capacity, and market attention. Besides, network information data was added to the evaluation system. Second, given the important role of the demand side in tourism, we took tourist demand as an indicator and therefore, our evaluation system included both supply and demand sides. It can not only reflect the actual level of tourism development in a region but also avoid the problem of a one-sided conclusion resulting from considering either the supply or demand side alone. Finally, according to the "13th Five-year Plan" of the Xinjiang tourism industry, four industrial belts were formed. We applied the Theil index to decompose the intragroup and intergroup differences of 14 Prefectures in accordance with the tourism in four industrial belts in Xinjiang. Therefore, the purpose and function of practical guidance of industrial belt planning are revealed. It will help us rethink the development and prospect of industrial belt tourism. By measuring the difference of various dimensions of tourism in the industrial belt, we will provide reference and basis for further strengthening industrial policies as well as regional cooperation policies and management of industrial belts, such as information sharing, resource complementation and industrial linkage.

\section{Materials and Methods}

\subsection{Balanced Scorecard}

A balanced scorecard (BSC) is one of the most used performance appraisal methods. We start from four angles-finance, customer, internal operation, and learning and growth-to measure an organization's implementation of its strategy using some actionable measurement indexes and target values. It is a new performance management method, with an emphasis on the past, present, and future realization ability. Applying it to the evaluation structure can make the evaluation system more comprehensive in assessing tourism development. In our study, we applied the principle of the balanced scorecard and added the contribution rate of tourism to tertiary industry GDP and the consumer feedback as the tourism performance index to our selection of indicators. It can reflect the "quantity" and "quality" of the performance and show the survival and development ability of the tourism industry. The ratio of tourism resource quality to tourism resource abundance is used as the index of tourism resource utilization. It fully embodies the degree of congenital tourism resource utilization and indicates business capability of the tourism industry.

For the measurement indexes of tourism's essential supporting capacity, the categories of per capita green space area, per capita fixed assets of accommodation and catering, number of beds per capita, number of public toilets per capita, traffic facilities construction and human resource support were selected. This selection will comprehensively reflect the satisfaction degree of the tourism industry's response to customers' basic needs. Selecting Baidu Index and attention index as market attention index may objectively and accurately reflect the attention of the tourism industry, showing the ability of the tourism industry to attract customers and improve itself. Combining the four dimensions, the evaluation 
system can comprehensively reflect the past, present, and future value realization ability of the regional tourism system.

\subsection{Analytic Hierarchy Process}

When faced with multiobjective decision-making problems, the method of the analytic hierarchy process can, to some extent, accurately describe the weight of different objectives for the final decision. Thus, we can see the importance of different objectives and set the priorities accordingly. Analytic hierarchy helps us make the most profitable decision. The basic steps are as follows:

First, the judgment matrix A is constructed by the consistent matrix method, multiplying all the elements in each row of A. Then, we calculate the n-th Root,

$$
\overline{\mathrm{w}}_{\mathrm{i}}=\sqrt[n]{\prod_{\mathrm{j}=1}^{\mathrm{n}} \mathrm{a}_{\mathrm{ij}}}
$$

where $\mathrm{i}=1,2, \ldots, \mathrm{n}$.

Second, $\overline{\mathrm{w}}_{\mathrm{i}}$ is obtained by normalizing $\mathrm{w}_{\mathrm{i}}$ and form the approximate eigenvector value $\mathrm{W}$ of the judgment matrix

$$
\mathrm{w}_{\mathrm{i}}=\frac{\overline{\mathrm{w}}_{\mathrm{i}}}{\sum_{\mathrm{i}=1}^{\mathrm{n}} \mathrm{w}_{\mathrm{i}}}, \mathrm{W}=\left[\mathrm{w}_{1}, \mathrm{w}_{2}, \ldots, \mathrm{w}_{\mathrm{n}}\right]^{\mathrm{T}}
$$

Finally, the maximum eigenvalue $\lambda_{\max }$ of the eigenvector $\mathrm{W}$ is calculated

$$
\lambda_{\max }=\frac{1}{\mathrm{n}} \sum_{\mathrm{i}=1}^{\mathrm{n}} \frac{(\mathrm{AW})_{\mathrm{i}}}{\mathrm{w}_{\mathrm{i}}}
$$

In addition, to test whether the weight is scientific, the consistency test was carried out by combining the consistency index CI and the test coefficient CR as defined in the following equations, respectively (Equations (4) and (5)).

$$
\begin{gathered}
\mathrm{CI}=\frac{\lambda_{\max }-\mathrm{n}}{\mathrm{n}-1} \\
\mathrm{CR}=\frac{\mathrm{CI}}{\mathrm{RI}}
\end{gathered}
$$

where $\mathrm{RI}$ is the average random consistency index. If $\mathrm{CR}<0.1$, it means the consistency test passes, so the weight is reasonable.

\subsection{Theil Index}

From the perspective of information quantity and entropy, the Theil index tells us about the unfairness and difference. It can be used to decompose the overall differences into intraregional differences and inter-regional differences. At the same time, it analyzes the characteristics of the overall differences and the evolution of regional differences. The numerical value is directly proportional to the imbalance between regions. The higher the Theil index is, the smaller the difference is. On the contrary, the greater the difference is. The formula for calculating the Theil index is as follows:

Theil index of tourism development difference degree between Prefectures inside one industrial belt is defined as follows (Equation (6)):

$$
\mathrm{T}_{\mathrm{pi}}=\sum_{\mathrm{j}} \frac{\mathrm{Y}_{\mathrm{ij}}}{\mathrm{Y}_{\mathrm{i}}} \ln \frac{\mathrm{Y}_{\mathrm{ij}}}{\frac{\mathrm{Y}_{\mathrm{i}}}{\mathrm{N}_{\mathrm{i}}}}
$$

where $\mathrm{T}_{\mathrm{pi}}$ is the Theil index of tourism development difference degree between Prefectures inside one industrial belt. $\mathrm{Y}_{\mathrm{ij}}$ and $\mathrm{N}_{\mathrm{ij}}$ are the scores and population of each dimension for 
prefecture $j$ in industrial belt $i$, respectively. $Y_{i}$ and $N_{i}$ are the scores and population of each dimension for industrial belt $i$, respectively.

Theil index of tourism development difference between industrial belts is defined as follows (Equation (7)):

$$
\mathrm{T}_{\mathrm{br}}=\sum_{\mathrm{i}} \frac{\mathrm{Y}_{\mathrm{i}}}{\mathrm{Y}} \ln \frac{\frac{\mathrm{Y}_{\mathrm{i}}}{\mathrm{Y}}}{\frac{\mathrm{N}_{\mathrm{i}}}{\mathrm{N}}}
$$

where $T_{b r}$ is the Theil index of tourism development difference between industrial belts. $Y_{i}$ and $\mathrm{N}_{\mathrm{i}}$ are the scores and population of each dimension for industrial belt $\mathrm{i}$, respectively. $\mathrm{Y}$ and $\mathrm{N}$ are the scores and population of each dimension for all industrial belts, respectively.

Taking Prefectures as a unit, the Theil index of tourism development's total difference degree

$$
\mathrm{T}_{\mathrm{p}}=\sum_{\mathrm{i}} \sum_{\mathrm{j}} \frac{\mathrm{Y}_{\mathrm{ij}}}{\mathrm{Y}} \ln \frac{\frac{\mathrm{Y}_{\mathrm{ij}}}{\mathrm{Y}}}{\frac{\mathrm{N}_{\mathrm{ij}}}{\mathrm{N}}}
$$

where $T_{p}$ is the Theil index of tourism development's total difference degree. $Y_{i j}$ and $\mathrm{N}_{\mathrm{ij}}$ are the scores and population of each dimension for prefecture $\mathrm{j}$ in industrial belt $\mathrm{i}$, respectively. $\mathrm{Y}$ and $\mathrm{N}$ are the scores and population of each dimension for all industrial belts, respectively. The difference in tourism development in Xinjiang can be divided into the sum of $\mathrm{T}_{\mathrm{wr}}$ and $\mathrm{T}_{\mathrm{br}}$

$$
\mathrm{T}_{\mathrm{p}}=\sum_{\mathrm{i}} \sum_{\mathrm{j}} \frac{\mathrm{Y}_{\mathrm{ij}}}{\mathrm{Y}} \ln \frac{\frac{\mathrm{Y}_{\mathrm{ij}}}{\mathrm{Y}}}{\frac{\mathrm{N}}{\mathrm{N}}}=\sum_{\mathrm{i}} \frac{\mathrm{Y}_{\mathrm{i}}}{\mathrm{Y}} \mathrm{T}_{\mathrm{pi}}+\mathrm{T}_{\mathrm{br}}=\mathrm{T}_{\mathrm{wr}}+\mathrm{T}_{\mathrm{br}}
$$

where $Y_{i j}$ and $N_{i j}$ are the scores and population of each dimension for prefecture $j$ in industrial belt $i$, respectively. $Y_{i}$ and $N_{i}$ are the scores and population of each dimension for industrial belt $\mathrm{i}$, respectively. $\mathrm{Y}$ and $\mathrm{N}$ are the scores and population of each dimension for all industrial belts, respectively.

\subsection{Entropy Method}

The entropy method can be used to judge the degree of indicators' dispersion. The greater the degree of indicators' dispersion is, the greater the indicators' impact on the comprehensive evaluation is. According to the entropy method, the tourism development of different dimensions for each industrial belt in Xinjiang can be compared. Based on the dimensionless processing of the original statistical data, the calculation steps are as follows:

The characteristic proportion of the $j$-th dimension in the $i$-th industrial belt

$$
P_{i j}=\frac{X_{i j}}{\sum_{i=1}^{n} X_{i j}}
$$

where $P_{\mathrm{ij}}$ is the characteristic proportion of the $\mathrm{j}$-th dimension in the $\mathrm{i}$-th industrial belt. $X_{\mathrm{ij}}$ is the score of the $\mathrm{j}$-th dimension in the $\mathrm{i}$-th industrial belt.

The entropy of each dimension

$$
\mathrm{e}_{\mathrm{j}}=-\frac{1}{\ln \mathrm{n}} \sum_{\mathrm{i}=1}^{\mathrm{n}} \mathrm{P}_{\mathrm{ij}} \ln \mathrm{P}_{\mathrm{ij}}
$$

where $e_{j}$ is the entropy of each dimension $j . P_{i j}$ is the characteristic proportion of the $j$-th dimension in the $\mathrm{i}$-th industrial belt, and $\mathrm{n}$ is the number of the industrial belts.

The difference coefficient of each dimension

$$
\mathrm{g}_{\mathrm{j}}=1-\mathrm{e}_{\mathrm{j}}
$$

where $g_{j}$ is the dimension of the difference coefficient of $j . e_{j}$ is the entropy of dimension $j$. 


\section{Results}

\subsection{Construction of Comprehensive Evaluation System of Tourism Development}

3.1.1. Construction of Evaluation System

Based on the Balanced Scorecard theory, we constructed the comprehensive evaluation system of Xinjiang tourism development. First, tourism performance is the most direct dimension to measure tourism development. Performance directly supports the development of tourism and reflects the past value ability. From the perspective of performance scoring, we selected the contribution rate of tourism to the tertiary industry GDP and consumer feedback as the measurement indicators of tourism performance. They respectively reflect the "quantity" and "quality" of performance. The addition of consumer feedback can overcome the shortcomings of only selecting the "quantity" level indicators in previous studies. Second, as the inherent condition of tourism development, tourism resources directly affect tourists' experience, perception, and evaluation. It also reflects the existing development ability. From the perspective of resource utilization scoring, we selected the ratio of tourism resource quality to tourism resource abundance as the measurement index of tourism resource utilization. They show the utilization of tourism resources and improve the deficiency of only focusing on the tourism resource absolute scale in previous studies. Third, market attention reflects tourists' interest, so it indirectly reflects the degree of development, utilization, and protection of tourist resources and reflects the existing development ability. However, the existing studies pay less attention to the demand side of tourism. We added the degree of market attention and selected Baidu Index and attention index as the index of market attention from the perspective of market attention scoring to greatly reduce the subjective error when using tourist questionnaire surveys in some studies. Finally, we selected tourism basic supporting capacity as an important indicator of tourism development. It interacts with the other three aspects and shows the future development potential. In order to accurately reflect the development of tourism, per capita green area, per capita fixed assets of accommodation and catering, number of beds per capita, number of public toilets per capita, traffic facilities construction and human resource support are selected as the measurement indicators of tourism basic supporting capacity. By means of the AHP method, based on the influence degree of various factors on tourism development and the availability, reliability, and accuracy of index data, we constructed a comprehensive evaluation system of Xinjiang tourism development from four aspects of tourism performance, tourism basic supporting capacity, tourism resource utilization and market attention, as shown in Tables 1-4.

Table 1. Comprehensive evaluation system in the dimension of tourism performance.

\begin{tabular}{|c|c|c|c|c|}
\hline $\begin{array}{l}\text { Balanced } \\
\text { Scoring }\end{array}$ & Rule Hierarchy & $\begin{array}{l}\text { First-Level } \\
\text { Indicators }\end{array}$ & $\begin{array}{l}\text { Second-Level } \\
\text { Indicators }\end{array}$ & $\begin{array}{l}\text { Third-Level } \\
\text { Indicators }\end{array}$ \\
\hline \multirow{7}{*}{$\begin{array}{c}\text { performance } \\
\text { scoring }\end{array}$} & \multirow{7}{*}{$\begin{array}{c}\text { tourism } \\
\text { performance }\end{array}$} & economic benefit & $\begin{array}{l}\text { contribution rate of } \\
\text { tourism to tertiary } \\
\text { industry GDP }\end{array}$ & \\
\hline & & \multirow{6}{*}{$\begin{array}{l}\text { consumer } \\
\text { feedback }\end{array}$} & \multirow{2}{*}{ scenic spot feedback } & scenic spot score \\
\hline & & & & $\begin{array}{l}\text { scenic spot } \\
\text { comment }\end{array}$ \\
\hline & & & \multirow{2}{*}{ hotel feedback } & hotel score \\
\hline & & & & hotel comment \\
\hline & & & \multirow{2}{*}{ restaurant feedback } & restaurant score \\
\hline & & & & $\begin{array}{c}\text { restaurant } \\
\text { comment }\end{array}$ \\
\hline
\end{tabular}


Table 2. Comprehensive evaluation system in the dimension of tourism resource utilization.

\begin{tabular}{ccccc}
\hline $\begin{array}{c}\text { Balanced } \\
\text { Scoring }\end{array}$ & Rule Hierarchy & $\begin{array}{c}\text { First-Level } \\
\text { Indicators }\end{array}$ & $\begin{array}{c}\text { Second-Level } \\
\text { Indicators }\end{array}$ & $\begin{array}{c}\text { Third-Level } \\
\text { Indicators }\end{array}$ \\
\hline $\begin{array}{c}\text { resource } \\
\text { utilization } \\
\text { scoring }\end{array}$ & $\begin{array}{c}\text { tourism resource } \\
\text { utilization }\end{array}$ & $\begin{array}{c}\text { the ratio of tourism } \\
\text { resource quality to } \\
\text { tourism resource } \\
\text { abundance }\end{array}$ & \\
\hline
\end{tabular}

Table 3. Comprehensive evaluation system in the dimension of market attention.

\begin{tabular}{|c|c|c|c|c|}
\hline $\begin{array}{c}\text { Balanced } \\
\text { Scoring }\end{array}$ & $\begin{array}{c}\text { Rule } \\
\text { Hierarchy }\end{array}$ & $\begin{array}{l}\text { First-Level } \\
\text { Indicators }\end{array}$ & $\begin{array}{l}\text { Second-Level } \\
\text { Indicators }\end{array}$ & $\begin{array}{l}\text { Third-Level } \\
\text { Indicators }\end{array}$ \\
\hline \multirow{4}{*}{$\begin{array}{l}\text { market } \\
\text { attention } \\
\text { scoring }\end{array}$} & \multirow{4}{*}{$\begin{array}{c}\text { market } \\
\text { attention }\end{array}$} & Baidu Index & $\begin{array}{l}\text { the proportion of } \\
\text { regional tourism } \\
\text { Baidu Index in } \\
\text { regional Baidu Index }\end{array}$ & \\
\hline & & \multirow{3}{*}{ attention index } & $\begin{array}{l}\text { scenic spot attention } \\
\text { index }\end{array}$ & $\begin{array}{l}\text { the proportion of the } \\
\text { number of scenic } \\
\text { spot attention in the } \\
\text { actual number of } \\
\text { attractions }\end{array}$ \\
\hline & & & hotel attention index & $\begin{array}{l}\text { the proportion of the } \\
\text { number of hotel } \\
\text { attention in the actual } \\
\text { number of hotels }\end{array}$ \\
\hline & & & $\begin{array}{l}\text { restaurant attention } \\
\text { index }\end{array}$ & $\begin{array}{l}\text { the proportion of the } \\
\text { number of restaurant } \\
\text { attention in the } \\
\text { actual number of } \\
\text { restaurants }\end{array}$ \\
\hline
\end{tabular}

The following is the explanation of each index in the evaluation. The contribution rate of tourism to the GDP of the tertiary industry is calculated as the ratio of tourism income added value in 2018 to the tertiary industry GDP added value in 2018. They are calculated according to the comparable prices in 1978 and can reflect the absolute and the relative scale simultaneously. The ratio of tourism income added value to GDP added value is commonly used. However, the primary and secondary industry GDP in some Prefectures of Xinjiang showed a declining trend, so the GDP growth is negative. To reflect the contribution of tourism more detailed and accurate, we selected the ratio of tourism income added value and the tertiary industry GDP added value. Consumer feedback reflects the "quality" of tourism performance. It is divided into scenic spot feedback, hotel feedback, and restaurant feedback. All of them include scores and comments. The tourism resource abundance is based on the investigation report on key tourism resources in Xinjiang and the classification, investigation, and evaluation of tourism resources. From the two aspects of resource value and utilization conditions, the comprehensive evaluation system of tourism resources development potential is constructed. Meanwhile, the statistical table of excellent tourism resources of various Prefectures is obtained. It represents the innate resource endowment. The quality of tourism resources includes A-level attraction resource and global tourism demonstration areas. It represents the acquired tourism resources. The tourism resource utilization degree is the ratio of the tourism resource quality to the tourism resource abundance, and it reflects the utilization degree of congenital resources. Baidu Index is the proportion of regional tourism Baidu Index in regional Baidu Index. It reflects the proportion of tourism search when performing a search in a region and represents the degree of A-level tourists' interest in regional tourism. The number of scenic spots on the internet divided by the attractions' actual number is the scenic spot attention index. The 
scope of scenic spot data is far broader than A-level attractions. It includes a variety of tourist attractions, such as a farmhouse, square, night market, cultural centers, libraries, museums, etc. Therefore, the ratio not only reflects the diversification and multiformat of tourist attractions but also the attention to scenic spots. Hotel attention is the proportion of hotel attention to the actual number of hotels. Likewise, restaurant attention is the proportion of restaurant attention to the actual number of restaurants. They reflect the attention to the accommodation and catering industry.

Table 4. Comprehensive evaluation system in the dimension of tourism basic supporting capacity.

\begin{tabular}{|c|c|c|c|c|}
\hline $\begin{array}{l}\text { Balanced } \\
\text { Scoring }\end{array}$ & Rule Hierarchy & $\begin{array}{l}\text { First-Level } \\
\text { Indicators }\end{array}$ & $\begin{array}{l}\text { Second-Level } \\
\text { Indicators }\end{array}$ & $\begin{array}{l}\text { Third-Level } \\
\text { Indicators }\end{array}$ \\
\hline \multirow{9}{*}{$\begin{array}{c}\text { basic } \\
\text { supporting } \\
\text { capacity scoring }\end{array}$} & \multirow{9}{*}{$\begin{array}{l}\text { tourism basic } \\
\text { supporting } \\
\text { capacity }\end{array}$} & $\begin{array}{c}\text { per capita green } \\
\text { area }\end{array}$ & & \\
\hline & & $\begin{array}{l}\text { per capita fixed } \\
\text { assets of } \\
\text { accommodation } \\
\text { and catering }\end{array}$ & & \\
\hline & & $\begin{array}{c}\text { number of beds } \\
\text { per capita }\end{array}$ & & \\
\hline & & $\begin{array}{l}\text { number of public } \\
\text { toilets per capita }\end{array}$ & & \\
\hline & & \multirow{3}{*}{$\begin{array}{l}\text { traffic facilities } \\
\text { construction }\end{array}$} & number of airlines & \\
\hline & & & $\begin{array}{l}\text { number of direct } \\
\text { railways }\end{array}$ & \\
\hline & & & $\begin{array}{c}\text { equivalent mileage } \\
\text { of highway }\end{array}$ & \\
\hline & & \multirow[b]{2}{*}{$\begin{array}{c}\text { human resource } \\
\text { support }\end{array}$} & $\begin{array}{c}\text { number of students } \\
\text { above secondary } \\
\text { level }\end{array}$ & \\
\hline & & & $\begin{array}{l}\text { number of } \\
\text { employees in } \\
\text { accommodation, } \\
\text { catering, and } \\
\text { attraction }\end{array}$ & \\
\hline
\end{tabular}

Per capita green area, the fixed assets of per capita accommodation and catering, number of beds per capita, number of public toilets per capita, traffic facilities construction and human resource support are used to reflect the tourism basic supporting capacity. Among these, the traffic facilities construction comprehensively considers three common ways for tourists to travel: aviation, railway, and highway. We selected the number of airlines, the number of direct railways and the equivalent highway mileage. Notably, with respect to equivalent highway mileage, we took the second-class highway as the standard. Other grade highways are converted into standard highway mileage to make highway mileage comparable. Human resource support includes the number of students above secondary level and the number of employees in accommodation, catering and attractions. The former reflects the "quality" of human resources. As an alternative indicator, the latter can be a proxy index representing employees of the tourism industry. Some researchers chose other alternative indicators in previous studies and enlarged the actual scale of tourism labor input. The indicators in this study can overcome that shortcoming and reflect the "quantity" of human resources. 


\subsubsection{Determination of Index Weight}

In the previous studies, neither the indicator construction nor the importance of indicators was consistent. Therefore, according to the law of domestic tourism development and its characteristics, the importance of each index in the criteria level is ranked in descending order as follows: tourism performance, tourism resource utilization, tourism basic supporting capacity, and market attention. We considered the relative importance of the economic benefit is greater than that of the consumer feedback; the internal relative importance of tourism basic supporting capacity is ranked in descending order as follows: traffic facilities construction, human resource support, per capita fixed assets of accommodation and catering, per capita green area, a number of public toilets per capita, and a number of beds per capita. The weight of scenic spot feedback, hotel feedback, and restaurant feedback, and the relative importance of scenic spot attention index, hotel attention index, and restaurant attention index is determined by the proportion of tourists' spending on sightseeing, accommodation and catering. The relative importance of the number of airlines, railway stations, and highway mileage is determined by the proportion of tourists' spending on airplanes, trains and long-distance buses. The specific judgment matrix is shown in Tables 5-8.

Table 5. Judgment matrix of rule hierarchy.

\begin{tabular}{ccccc}
\hline & $\begin{array}{c}\text { Tourism } \\
\text { Performance }\end{array}$ & $\begin{array}{c}\text { Tourism Basic Supporting } \\
\text { Capacity }\end{array}$ & $\begin{array}{c}\text { Tourism Resource } \\
\text { Utilization }\end{array}$ & $\begin{array}{c}\text { Market } \\
\text { Attention }\end{array}$ \\
\hline $\begin{array}{c}\text { tourism performance } \\
\text { tourism basic supporting } \\
\text { capacity }\end{array}$ & $1 / 1$ & $3 / 2$ & $9 / 5$ & $9 / 4$ \\
$\begin{array}{c}\text { tourism resource } \\
\text { utilization }\end{array}$ & $2 / 3$ & $1 / 1$ & $9 / 7$ & $3 / 2$ \\
market attention & $5 / 9$ & $7 / 9$ & $1 / 1$ & $9 / 5$ \\
\hline
\end{tabular}

Table 6. Judgment matrix of tourism basic supporting capacity.

\begin{tabular}{|c|c|c|c|c|c|c|}
\hline & $\begin{array}{c}\text { Traffic } \\
\text { Facilities } \\
\text { Construction }\end{array}$ & $\begin{array}{c}\text { Human } \\
\text { Resource } \\
\text { Support }\end{array}$ & $\begin{array}{l}\text { Per Capita Fixed } \\
\text { Assets of } \\
\text { Accommodation } \\
\text { and Catering }\end{array}$ & $\begin{array}{l}\text { Per Capita } \\
\text { Green Area }\end{array}$ & $\begin{array}{c}\text { Number of } \\
\text { Public Toilets } \\
\text { per Capita }\end{array}$ & $\begin{array}{l}\text { Number of } \\
\text { Beds per } \\
\text { Capita }\end{array}$ \\
\hline $\begin{array}{l}\text { traffic facilities } \\
\text { construction }\end{array}$ & $1 / 1$ & $9 / 8$ & $9 / 5$ & $9 / 4$ & $3 / 1$ & $9 / 2$ \\
\hline $\begin{array}{c}\text { human resource } \\
\text { support }\end{array}$ & $8 / 9$ & $1 / 1$ & $9 / 7$ & $3 / 2$ & $9 / 5$ & $9 / 4$ \\
\hline $\begin{array}{c}\text { per capita fixed } \\
\text { assets of } \\
\text { accommodation and } \\
\text { catering }\end{array}$ & $5 / 9$ & $7 / 9$ & $1 / 1$ & $9 / 7$ & $3 / 2$ & $9 / 5$ \\
\hline per capita green area & $4 / 9$ & $2 / 3$ & $7 / 9$ & $1 / 1$ & $3 / 2$ & $9 / 5$ \\
\hline $\begin{array}{l}\text { number of public } \\
\text { toilets per capita }\end{array}$ & $1 / 3$ & $5 / 9$ & $2 / 3$ & $2 / 3$ & $1 / 1$ & $9 / 8$ \\
\hline $\begin{array}{l}\text { number of beds per } \\
\text { capita }\end{array}$ & $2 / 9$ & $4 / 9$ & $5 / 9$ & $5 / 9$ & $8 / 9$ & $1 / 1$ \\
\hline
\end{tabular}

Table 7. Judgment matrix of scenic spots, hotels and restaurants.

\begin{tabular}{cccc}
\hline & Restaurants & Hotels & Scenic Spots \\
\hline restaurants & $1 / 1$ & $9 / 8$ & $9 / 2$ \\
hotels & $8 / 9$ & $1 / 1$ & $9 / 2$ \\
scenic spots & $2 / 9$ & $2 / 9$ & $1 / 1$ \\
\hline
\end{tabular}


Table 8. Judgment matrix of traffic facilities construction.

\begin{tabular}{cccc}
\hline & Number of Airlines & $\begin{array}{c}\text { Equivalent Mileage } \\
\text { of Highway }\end{array}$ & $\begin{array}{c}\text { Number of Direct } \\
\text { Railways }\end{array}$ \\
\hline $\begin{array}{c}\text { number of airlines } \\
\text { equivalent mileage of } \\
\text { highway }\end{array}$ & $1 / 1$ & $9 / 7$ & $3 / 1$ \\
$\begin{array}{c}\text { number of direct } \\
\text { railways }\end{array}$ & $7 / 9$ & $1 / 1$ & $9 / 4$ \\
\hline
\end{tabular}

According to the determined judgment matrix, the weight of each single index is determined by using the analytic hierarchy process. The results are shown in Tables 9-12.

Table 9. Weight table of indexes at all levels in tourism performance.

\begin{tabular}{|c|c|c|c|c|}
\hline Balanced Scoring & Rule Hierarchy & First-Level Indicators & $\begin{array}{l}\text { Second-Level } \\
\text { Indicators }\end{array}$ & Third-Level Indicators \\
\hline \multirow{7}{*}{ performance scoring } & \multirow{7}{*}{$\begin{array}{l}\text { tourism performance } \\
\qquad(0.3728)\end{array}$} & \multirow[t]{3}{*}{$\begin{array}{c}\text { economic benefit } \\
(0.1864)\end{array}$} & $\begin{array}{c}\text { contribution rate of } \\
\text { tourism to tertiary } \\
\text { industry GDP }(0.1864)\end{array}$ & \\
\hline & & & \multirow{2}{*}{$\begin{array}{c}\text { scenic spot feedback } \\
(0.0186)\end{array}$} & scenic spot score $(0.0436)$ \\
\hline & & & & $\begin{array}{c}\text { scenic spot comment } \\
(0.0436)\end{array}$ \\
\hline & & \multirow{4}{*}{$\begin{array}{c}\text { consumer feedback } \\
(0.1864)\end{array}$} & \multirow{2}{*}{ hotel feedback 0.0806) } & hotel score $(0.0403)$ \\
\hline & & & & hotel comment (0.0403) \\
\hline & & & \multirow{2}{*}{$\begin{array}{c}\text { restaurant feedback } \\
(0.0872)\end{array}$} & restaurant score $(0.0093)$ \\
\hline & & & & $\begin{array}{c}\text { restaurant comment } \\
(0.0093)\end{array}$ \\
\hline
\end{tabular}

Table 10. Weight table of indexes at all levels in tourism resource utilization.

\begin{tabular}{|c|c|c|c|c|}
\hline Balanced Scoring & Rule Hierarchy & First-Level Indicators & $\begin{array}{l}\text { Second-Level } \\
\text { Indicators }\end{array}$ & Third-Level Indicators \\
\hline $\begin{array}{l}\text { resource utilization } \\
\text { scoring }\end{array}$ & $\begin{array}{l}\text { tourism resource } \\
\text { utilization }(0.2230)\end{array}$ & $\begin{array}{l}\text { the ratio of tourism } \\
\text { resource quality to } \\
\text { tourism resource } \\
\text { abundance }(0.2230)\end{array}$ & & \\
\hline
\end{tabular}

According to Tables 9-12, the most important factors are the ratio of tourism resources quality to tourism resource abundance, economic benefits, and consumer feedback. Respectively, their weights are $0.2230,0.1864$, and 0.1864 . This indicates that these indicators have a significant impact on tourism development in Xinjiang. The indicators with the least weight are per capita green space area, per capita public toilets, and per capita number of accommodation beds. Respectively, their weights are $0.0355,0.0258$, and 0.0211 . This shows that these indicators have little influence on tourism development in Xinjiang. From the perspective of four dimensions, the indicator with the most significant weight is tourism performance, and it is 0.3728 . This indicates that tourism performance has the most significant impact on tourism development in Xinjiang. The weights of tourism basic supporting capacity and tourism resource utilization are 0.2529 and 0.2230 , respectively. The indicator with the least weight is market attention, and it is 0.1513 . This indicates that the market attention has minimal impact on Xinjiang tourism development. 
Table 11. Weight table of indexes at all levels in market attention.

\begin{tabular}{|c|c|c|c|c|}
\hline Balanced Scoring & Rule Hierarchy & First-Level Indicators & Second-Level Indicators & Third-Level Indicators \\
\hline \multirow{4}{*}{$\begin{array}{l}\text { market attention } \\
\text { scoring }\end{array}$} & \multirow{4}{*}{$\begin{array}{l}\text { market attention } \\
(0.1513)\end{array}$} & Baidu Index (0.0756) & $\begin{array}{l}\text { the proportion of regional } \\
\text { tourism Baidu Index in } \\
\text { regional Baidu Index } \\
(0.0756)\end{array}$ & \\
\hline & & \multirow{3}{*}{ attention index (0.0756) } & $\begin{array}{l}\text { scenic spot attention index } \\
(0.0076)\end{array}$ & $\begin{array}{l}\text { the proportion of the } \\
\text { number of scenic spot } \\
\text { attention in the actual } \\
\text { number of attractions } \\
(0.0076)\end{array}$ \\
\hline & & & $\begin{array}{l}\text { hotel attention index } \\
\qquad(0.0327)\end{array}$ & $\begin{array}{l}\text { the proportion of the } \\
\text { number of hotel attention } \\
\text { in the actual number of } \\
\text { hotels }(0.0327)\end{array}$ \\
\hline & & & $\begin{array}{l}\text { restaurant attention index } \\
(0.0354)\end{array}$ & $\begin{array}{l}\text { the proportion of the } \\
\text { number of restaurant } \\
\text { attention in the actual } \\
\text { number of restaurants } \\
(0.0354)\end{array}$ \\
\hline
\end{tabular}

Table 12. Weight table of indexes at all levels in tourism basic supporting capacity.

\begin{tabular}{|c|c|c|c|c|}
\hline Balanced Scoring & Rule Hierarchy & First-Level Indicators & Second-Level Indicators & $\begin{array}{l}\text { Third-Level } \\
\text { Indicators }\end{array}$ \\
\hline \multirow{9}{*}{$\begin{array}{l}\text { basic supporting } \\
\text { capacity scoring }\end{array}$} & \multirow{9}{*}{$\begin{array}{c}\text { tourism basic } \\
\text { supporting capacity } \\
(0.2529)\end{array}$} & $\begin{array}{l}\text { per capita green area } \\
(0.0355)\end{array}$ & & \\
\hline & & $\begin{array}{l}\text { per capita fixed assets of } \\
\text { accommodation and } \\
\text { catering }(0.0411)\end{array}$ & & \\
\hline & & $\begin{array}{l}\text { number of beds per capita } \\
\qquad(0.0211)\end{array}$ & & \\
\hline & & $\begin{array}{l}\text { number of public toilets } \\
\text { per capita }(0.0258)\end{array}$ & & \\
\hline & & \multirow{3}{*}{$\begin{array}{c}\text { traffic facilities } \\
\text { construction }(0.0763)\end{array}$} & number of airlines $(0.0362)$ & \\
\hline & & & $\begin{array}{l}\text { number of direct railways } \\
(0.0278)\end{array}$ & \\
\hline & & & $\begin{array}{l}\text { equivalent mileage of } \\
\text { highway }(0.0122)\end{array}$ & \\
\hline & & \multirow{2}{*}{$\begin{array}{l}\text { human resource support } \\
\qquad(0.0531)\end{array}$} & $\begin{array}{l}\text { number of students above } \\
\text { secondary level }(0.0265)\end{array}$ & \\
\hline & & & $\begin{array}{l}\text { number of employees in } \\
\text { accommodation, catering } \\
\text { and attraction }(0.0265)\end{array}$ & \\
\hline
\end{tabular}

\subsection{Empirical Analysis}

\subsubsection{Data Source and Description}

The data of this paper were collected from the 2019 Xinjiang statistical yearbook, 2018 Xinjiang Uygur Autonomous Region Statistical Bulletin on National Economic and Social Development, tourism official statistics and Internet data. The Internet data comes from ctrip (https: / / www.ctrip.com, accessed on 21 February 2021) and Baidu (https: / www. baidu.com, accessed on 21 February 2021), respectively. The data are collected to the level of 14 Prefectures. The specific collection situation is as follows: As a website with a 
high utilization rate, ctrip is used to collect data. Taking five elements of "eating, living, traveling, shopping, and entertainment" as the starting point, the relevant online data of 37,412 restaurants, 5339 hotels, 2149 scenic spots, 20,963 shopping places, and 15,645 travel notes were collected. The data includes scenic spot score, scenic spot comment, scenic spot attention, hotel score, hotel comment, hotel attention, restaurant score, restaurant comment, and restaurant attention by 2020. Baidu Index and the number of airlines come from Baidu, and Baidu Index is obtained by searching "Baidu Index". The tourism income added value, the tertiary industry GDP added value, the actual number of scenic spots, hotels and restaurants, A-level attractions, global tourism demonstration areas, per capita green area, per capita fixed assets of accommodation and catering, number of beds per capita, number of public toilets per capita, per capita number of direct railways, number of students above secondary level, and number of employees in accommodation, catering, and attraction are from Xinjiang tourism bureau data of relevant departments in 2018 . Considering data availability, we choose to use the highway data of various Prefectures in Xinjiang in 2019 as equivalent mileage of highway. The abundance of tourism resources has not changed a lot in a short time, so the data in the investigation report on key tourism resources in Xinjiang is selected.

\subsubsection{Data Standardization}

In order to eliminate the influence of data size and unit, we adopted different methods for standardization according to the data type and characteristics of each index:

(1) For quantitative indicators, the following standardized treatment is carried out to eliminate the influence of zero value and negative value in the subsequent calculation, and the formula is as follows:

$$
\mathrm{I}_{\mathrm{ij}}=\frac{\mathrm{a}_{\mathrm{ij}}-\min \left(\mathrm{a}_{\mathrm{ij}}\right)}{\max \left(\mathrm{a}_{\mathrm{ij}}\right)-\min \left(\mathrm{a}_{\mathrm{ij}}\right)}+0.0001
$$

where $\mathrm{I}_{\mathrm{ij}}$ is the score of the $\mathrm{j}$-th factor of the $\mathrm{i}$-th indicator, and $\mathrm{a}_{\mathrm{ij}}$ is the actual value of the $\mathrm{j}$-th factor of the $\mathrm{i}$-th indicator.

(2) For qualitative indicators, the score is given in accordance with the grade. According to the detailed rules for evaluating national standards in "evaluation and division of the quality level of tourist attractions", A-level scenic area resources are given 1130 points, 1010 points, 890 points, 720 points, and 600 points from 5A to A, respectively. The global tourism demonstration area is given 1000 points according to the "accepted standard of the state of global tourism demonstration area". After the score is given, it is processed according to the standardized method of the quantitative index.

\subsubsection{Calculation of Xinjiang Tourism Development Level}

After the data of each index is standardized, the score of each dimension is calculated according to the weight of each level index in the evaluation system

$$
\mathrm{Y}=\sum_{\mathrm{i}=1}^{\mathrm{n}} \mathrm{w}_{\mathrm{i}} \times \mathrm{g}_{\mathrm{i}}
$$

where $\mathrm{Y}$ is the score of a certain dimension in a region; for a certain dimension, $\mathrm{w}_{\mathrm{i}}$ is the standardized value of each index; $g_{i}$ is the weight of each index.

By adding the scores of each dimension, we received the comprehensive scores of 14 Prefectures in Xinjiang, and the results are shown in Table 13. 
Table 13. Tourism development evaluation of 14 Prefectures in Xinjiang.

\begin{tabular}{|c|c|c|c|c|c|c|c|c|c|c|c|}
\hline $\begin{array}{l}\text { Industrial } \\
\text { Belt }\end{array}$ & Area & $\begin{array}{c}\text { Tourism } \\
\text { Performance }\end{array}$ & Ranking & $\begin{array}{c}\text { Tourism Basic } \\
\text { Supporting Capacity }\end{array}$ & Ranking & $\begin{array}{c}\text { Tourism Resource } \\
\text { Utilization }\end{array}$ & Ranking & $\begin{array}{c}\text { Market } \\
\text { Attention }\end{array}$ & Ranking & $\begin{array}{l}\text { Comprehensive } \\
\text { Score }\end{array}$ & Ranking \\
\hline \multirow{5}{*}{1} & a Yili & 0.2322 & 2 & 0.0501 & 9 & 0.1028 & 2 & 0.1214 & 1 & 0.5065 & 2 \\
\hline & Bozhou & 0.1042 & 9 & 0.0305 & 12 & 0.0420 & 8 & 0.0370 & 9 & 0.2136 & 11 \\
\hline & Changji & 0.1995 & 3 & 0.0418 & 11 & 0.0925 & 3 & 0.0395 & 7 & 0.3733 & 5 \\
\hline & Turpan & 0.1876 & 6 & 0.0941 & 3 & 0.0483 & 7 & 0.0618 & 2 & 0.3918 & 4 \\
\hline & Hami & 0.0818 & 11 & 0.0798 & 6 & 0.0244 & 10 & 0.0309 & 11 & 0.2169 & 10 \\
\hline \multirow{2}{*}{2} & Altay & 0.2663 & 1 & 0.0922 & 4 & 0.0375 & 9 & 0.0596 & 3 & 0.4556 & 3 \\
\hline & Karamay & 0.1057 & 8 & 0.0995 & 2 & 0.0715 & 5 & 0.0494 & 5 & 0.3261 & 7 \\
\hline \multirow{5}{*}{3} & Bazhou & 0.1993 & 4 & 0.0896 & 5 & 0.0119 & 13 & 0.0367 & 10 & 0.3374 & 6 \\
\hline & Kashi & 0.0908 & 10 & 0.0703 & 7 & 0.0855 & 4 & 0.0494 & 4 & 0.2960 & 9 \\
\hline & Kezhou & 0.0419 & 14 & 0.0234 & 14 & 0.0000 & 14 & 0.0183 & 14 & 0.0836 & 14 \\
\hline & Aksu & 0.0739 & 12 & 0.0629 & 8 & 0.0240 & 11 & 0.0387 & 8 & 0.1996 & 12 \\
\hline & Hotan & 0.0541 & 13 & 0.0245 & 13 & 0.0206 & 12 & 0.0304 & 12 & 0.1295 & 13 \\
\hline 4 & Urumqi & 0.1955 & 5 & 0.1700 & 1 & 0.2230 & 1 & 0.0186 & 13 & 0.6071 & 1 \\
\hline
\end{tabular}

a Yili represents the Counties (Cities) Directly Under Yili Prefecture. 
It can be seen from Table 13 that the tourism development level of Urumqi is the highest, and its tourism basic supporting capacity and tourism resource utilization rank first. The tourism basic supporting capacity of Urumqi is high mainly due to its transportation facilities construction, human resource support, per capita accommodation and catering fixed assets, and per capita accommodation beds. The high utilization of resources in Urumqi is mainly due to the good development of natural resources. Urumqi's market attention ranks 13th because there are a lot of local restaurants, but the attention on the internet is relatively insufficient. Thus, the market attention is low due to the extremely low degree of restaurant attention. Secondly, the Counties (Cities) Directly Under Yili Prefecture and Altay have a higher contribution rate of tourism income to the tertiary industry GDP due to the higher scores of tourism performance and market attention, and the online attention of hotels in the region. Kezhou and Hotan have the lowest level of development. The tourism performance, tourism basic supporting capacity, resource utilization, and market attention of the two Prefectures are in the lower position among the 14 Prefectures. This finding indicates that for Kezhou and Hotan, there is more potential for improvement. Their low performance results from the relative lack of tourism resources and the inadequate tourism basic supporting facilities such as transportation construction, human resources, accommodation, catering, and public toilets. It is also closely related to the lack of market attention.

From the perspective of tourism resource and development ability, the difference in tourism resource utilization in different Prefectures of the industrial belt is the most significant. Tourism resources are essential to attract tourists. Tourists are the necessary condition for regional tourism development. The tourism-industrial belt linkage oriented by tourists' demand is the most effective choice for regional tourism development. Tourism in the industrial belt is defined by the characteristics of the region and its resource, and thus it may ignore the diversity of tourists' growing demands and differentiated choices. It may lead to the decline of the overall performance of industrial belt tourism. Meanwhile, the differentiated development of tourism resources in the industry belt may lead to the decline of tourist satisfaction and may also damage the overall image of the region. The development of tourism resources may take a significant amount of time. The development cycle is long, and the investment is large, so the possibility of improving the resource development level in the short term is minimal. Given the characteristics of Xinjiang's large spatial area, it is necessary to plan and design the industrial belt in a smaller scope so that the industrial belt can truly interact with regional activities based on the needs of tourists and the characteristics of resources.

From the perspective of market attention, the difference in market attention among the five cities in the Tianshan corridor (part of the UNESCO world heritage list) industry belt is the most significant, while the tourism performance is the smallest. Ili and Turpan have the highest score in market attention, and Hami has the lowest score. The reason is that Ili focuses on building the Tianshan Heritage corridor, forming the core products of Ili international tourism Valley, and building large-scale original ecological people cultural tourism Prefectures. With the development of information technology, people depend on information more and more. The network and mobile networks have become the main channels for the public to obtain information. With the arrival of the mass tourism era and global tourism era, regional tourism attention will significantly stimulate tourists enthusiasm and destination choices. The change in the attention index is closely related to the regional marketing activities, image publicity, and the network marketing level of tourism enterprises. Ili is the region with the most abundant tourism resources. In recent years, with the continuous increase of publicity, the market attention has increased and helps to improve the overall performance of regional tourism. Turpan and Hami are located in the eastern part of the Tianshan Mountains, so they have not received enough market attention. Hami, in particular, should reposition the collaborative relationship with Ili and determine the industrial linkage area according to the characteristics of tourists' behaviors and their consumptions. 
From the perspective of infrastructure, the preferred tourism infrastructure would be more conducive to regional tourism development. Tourists' needs are diverse, and tourists' attention and satisfaction are also the expressions of their overall state. From the data, there is a close relationship between the regional GDP and the supporting capacity of regional infrastructure, and the latter depends on the development capacity of the regional economy. Infrastructure supporting capacity also influences the market attention. The market attention index changes independent of any one particular index and is formed according to the overall image of the region and tourism experience service. At the same time, it will feed back into society. Thus, it is an important factor to affect tourists, and the study shows that strengthening the tourism basic supporting capacity can greatly improve the market attention.

\subsubsection{Overall Evaluation of Tourism Development in Various Industrial Belts}

According to the "13th Five-year Plan" for Tourism Development in Xinjiang Uygur Autonomous Region, 14 Prefectures in Xinjiang are divided into four industrial belts. Industrial belt 1 is the Tianshan corridor world heritage industrial belt, including Ili Prefecture, Bozhou, Changji, Turpan, and Hami. Industrial belt 2 is an ecotourism industrial belt in the northern margin of Junggar, including Altay, Tacheng, and Karamay. Industrial belt 3 is the cultural and ethnic tourism destination along the Silk Road in southern Xinjiang, including Kashgar, Aksu, Bazhou, Hotan, and Kezhou. Industrial belt 4 is Urumqi International Tourism Distribution Center, including Urumqi alone. According to the four industrial belts and the 14 Prefectures' scores of different dimensions in Table 13, we aggregated the scores of corresponding Prefectures according to the tourism industrial belt and calculated their average. Thus, we obtained the overall tourism development evaluation for each industrial belt. The results are shown in Table 14.

Table 14. Industrial belt's overall evaluation of tourism development in Xinjiang.

\begin{tabular}{cccccc}
\hline & $\begin{array}{c}\text { Tourism } \\
\text { Performance }\end{array}$ & $\begin{array}{c}\text { Tourism Basic } \\
\text { Supporting } \\
\text { Capacity }\end{array}$ & $\begin{array}{c}\text { Tourism } \\
\text { Resource } \\
\text { Utilization }\end{array}$ & $\begin{array}{c}\text { Market } \\
\text { Attention }\end{array}$ & $\begin{array}{c}\text { Overall } \\
\text { Score }\end{array}$ \\
\hline belt 1 & 0.1610 & 0.0593 & 0.0620 & 0.0581 & 0.3404 \\
belt 2 & 0.1806 & 0.0787 & 0.0583 & 0.0511 & 0.3687 \\
belt 3 & 0.0920 & 0.0541 & 0.0284 & 0.0347 & 0.2092 \\
belt 4 & 0.1955 & 0.1700 & 0.2230 & 0.0186 & 0.6071 \\
\hline
\end{tabular}

Table 14 shows that: as the international tourism distribution center and the capital city of Xinjiang, Urumqi has the highest level of tourism development. It is the hub of politics, economy, culture, and transportation in Xinjiang and ranks first in tourism performance, tourism basic supporting capacity, and resource utilization. Having the Counties (Cities) Directly Under Yili Prefecture, Bozhou, Changji, Turpan, and Hami as the core, Tianshan corridor World Heritage tourism industrial belt has the Ili River Valley. The Ili River Valley has the highest resource enrichment, so the tourism resource utilization of this industrial belt ranks second. Due to the influence of Bozhou and Hami, it ranks third overall, and the difference within the industrial belt is the largest. The eco-tourism industrial belt in the northern margin of Junggar ranks second overall, and Altay is the driving role of this belt. The overall tourism ranking of the five Prefectures in southern Xinjiang is the lowest. The main reason is that regional economic development affects the construction of regional infrastructure and the creation and innovation of tourism brands and formats. In addition, the relatively arid climate and local geographical conditions affect tourists' desire to southern Xinjiang. The transportation cost and time also affect the development of tourism in southern Xinjiang. All factors above hindered the development of local tourism. 


\subsubsection{The Evaluation of Tourism Development Differences of Various Industrial Belts}

In terms of tourism development, there are differences within tourism of one industrial belt and differences between tourism in different industrial belts. Different industrial belts have their own development plans. Moderate industrial belt differences play a positive role in promoting the development of tourism. It can promote the spatial flow of production factors and optimize the allocation of resources to a certain extent. However, excessive differences will lead to the concentration of various resources in developed Prefectures, expand the gap, and affect the overall tourism development in Xinjiang. Therefore, to promote the sustainable development of tourism, it is necessary to make a quantitative analysis of the regional differences. Thus, the Theil index is applied to the tourism industry in Xinjiang. It can measure the difference of tourism development within one belt and the differences between the industrial belts and help provide a reference for the tourism development in the industrial belts as well as different Prefectures.

According to the tourism development scores of 14 Prefectures in Xinjiang from Table 7, the Theil index of tourism performance, tourism basic supporting capacity, resource utilization and market attention are calculated using Equations (6)-(9). The results are shown in Table 15.

Table 15. The Theil index of various dimensions in Xinjiang.

\begin{tabular}{ccccccc}
\hline Dimension & Belt1 & Belt2 & Belt3 & $\begin{array}{c}\text { The Difference } \\
\text { within Belt }\end{array}$ & $\begin{array}{c}\text { The Difference } \\
\text { between Belts }\end{array}$ & $\begin{array}{c}\text { Overall } \\
\text { Difference }\end{array}$ \\
\hline $\begin{array}{c}\text { tourism performance } \\
\text { tourism basic } \\
\begin{array}{c}\text { supporting capacity } \\
\text { tourism resource }\end{array}\end{array}$ & 0.0497 & 0.0211 & 0.0873 & 0.1581 & 0.1482 & 0.3063 \\
$\begin{array}{c}\text { utilization } \\
\text { market attention }\end{array}$ & 0.1499 & 0.0698 & 0.0633 & 0.2730 & 0.0778 & 0.3508 \\
\hline
\end{tabular}

By analyzing the Theil index of various dimensions in Xinjiang, we can see that in the dimension of tourism performance, the Theil index within and between the industrial belt is relatively similar. In the dimension of tourism basic supporting capacity, resource utilization and market attention, the difference within the industrial belt is significantly greater than that between industrial belts. It shows that the differences mainly come from the differences among the Prefectures in the industrial belt. In all dimensions, the differences within the industrial belt are greater than the differences between the industrial belts. It tells us that the differences within the industrial belt are the main reasons for the overall differences. Therefore, it is necessary to analyze further the differences of each industrial belt with the entropy method and calculate the difference coefficient according to Equations (10)-(12). The results are shown in Table 16.

From the perspective of all industrial belts, the difference in tourism resource utilization is the largest. Tourism basic supporting capacity and tourism performance rank second and third, respectively. The difference in market attention is the smallest. By analyzing the differences of each dimension in each industrial belt, the dimensions with the most and the least significant difference are obtained. The difference coefficient of four dimensions in the Tianshan corridor world heritage tourism industrial belt is relatively high. The most significant difference coefficient is the market attention. The reason is that the Baidu Index of each area is significantly different. The biggest difference coefficient of the ecotourism industrial belt in the northern margin of Junggar is tourism performance, and the contribution rate of tourism to the tertiary industry GDP is quite different. The smallest difference coefficient is market attention, and its attention index is high. Meanwhile, the difference in Baidu Index is slight. The biggest difference coefficient of the cultural and ethnic tourism destination along the Silk Road in southern Xinjiang is resource utilization. It has significant differences in resource development. The smallest difference coefficient is market attention because Baidu Index is small, and the score for the attention index is relatively balanced. Overall, 
the most significant difference coefficient in Xinjiang is tourism resource utilization, and the smallest difference coefficient is market attention. This result shows a significant gap in the utilization of inherent tourism resources in various industrial belts. With respect to the attention in the tourism industry, all Prefectures are doing the promotion, so the gap is reduced. In other words, it further confirms the necessity of considering the demand side in tourism development.

Table 16. Industrial belt development differences of various dimensions.

\begin{tabular}{|c|c|c|c|c|c|}
\hline Industrial Belt & Index & $\begin{array}{c}\text { Tourism } \\
\text { Performance }\end{array}$ & $\begin{array}{c}\text { Tourism Basic } \\
\text { Supporting Capacity }\end{array}$ & $\begin{array}{c}\text { Tourism Resource } \\
\text { Utilization }\end{array}$ & Market Attention \\
\hline \multirow{2}{*}{ belt 1} & \multirow{2}{*}{$\begin{array}{c}\text { entropy } \\
\text { difference } \\
\text { coefficient }\end{array}$} & 0.9572 & 0.9496 & 0.9241 & 0.9109 \\
\hline & & 0.0428 & 0.0504 & 0.0759 & 0.0891 \\
\hline \multirow{2}{*}{ belt 2} & \multirow{2}{*}{$\begin{array}{l}\text { entropy } \\
\text { difference } \\
\text { coefficient }\end{array}$} & 0.9390 & 0.9519 & 0.9681 & 0.9929 \\
\hline & & 0.0610 & 0.0481 & 0.0319 & 0.0071 \\
\hline \multirow{2}{*}{ belt 3} & \multirow{2}{*}{$\begin{array}{c}\text { entropy } \\
\text { difference } \\
\text { coefficient }\end{array}$} & 0.8987 & 0.9223 & 0.6803 & 0.9712 \\
\hline & & 0.1013 & 0.0777 & 0.3197 & 0.0288 \\
\hline \multirow{2}{*}{$\begin{array}{l}\text { All Prefectures in } \\
\text { Xinjiang }\end{array}$} & \multirow{2}{*}{$\begin{array}{l}\text { entropy } \\
\text { difference } \\
\text { coefficient }\end{array}$} & 0.9533 & 0.9467 & 0.8668 & 0.9540 \\
\hline & & 0.0467 & 0.0533 & 0.1332 & 0.0460 \\
\hline
\end{tabular}

\section{Tactics and Suggestions}

The evaluation of tourism development in Xinjiang is a complex problem. The construction of a scientific and accurate evaluation system can provide a reference for tourism development. Based on the summary of the classic literature, we started from the principle of a balanced scorecard and constructed a comprehensive evaluation system with indexes about the tourism development from four dimensions: tourism performance, tourism resource utilization, tourism basic supporting capacity, and market attention. Based on the tourism data of different regions in Xinjiang, we made further empirical analysis employing the AHP. Finally, we studied the differences of Xinjiang tourism industrial belts by the Theil index and entropy method. The results show that:

(1) Based on tourism resources and regional characteristics, industrial belt tourism does not form a comprehensive advantage. From the four dimensions, there is a phenomenon that the strong belt guides the weak belt. There are high-ranking and lowranking Prefectures in the same industrial belt simultaneously. The development of Prefectures in the industrial belt is different, and the differences within the industrial belt are more significant than those among the industrial belts. Therefore, according to the inherent relevance of tourism resources and the proximity of geographical space, the industrial belt tourism cooperation should be paid attention to, which means the linkage of the industrial belt has become the most prominent problem.

(2) For the five Prefectures in the Tianshan corridor World Heritage Tourism Industrial Belt (Xinjiang, China), transportation is an essential factor affecting tourists' behavior in the tourism region. Due to the different transportation factors in using aviation, railway, and highway, it is necessary to further refine the industrial belt according to the regional track characteristics of tourists and then to readjust the industrial linkage area taking a good case as an example to follow to strengthen the internal linkage of the industrial belt.

(3) For the three Prefectures in the ecotourism industrial belt in the northern margin of Junggar, the difference in tourism performance is the biggest, and the difference in market attention is the smallest. It indicates that publicity and promotion of Prefectures are relatively good and should be maintained. Altay has the highest 
score of tourism performance, while Karamay's tourism performance is the lowest. The reason is that Altay relies on Altai Mountain to create tourism hotspots and launch Altai Mountain ecotourism routes. Then, it will promote the development of surrounding scenic spots and industrial bases. However, Karamay has a small geographical area and insufficient tourism products, leading to relatively low tourism performance. Therefore, Karamay should build a capital of petroleum culture, as well as a city of leisure and fashion. It is helpful to build a base for exhibition and sales of tourism commodities with Xinjiang characteristics.

(4) For the five Prefectures in the cultural and ethnic tourism destination along the Silk Road in southern Xinjiang, the difference of resource utilization is the biggest, and the smallest is the market attention. It shows that the marketing and publicity of each city are insufficient, so it is necessary to strengthen the brand building, expand publicity and generate greater attention. The highest score of tourism resource utilization is Kashi, and the scores of other Prefectures are very low. It is closely related to Kashi's combination of world cultural heritage declaration and world-class scenic spot construction. Meanwhile, Kashi is devoted to developing tourism resources, creating theme tourism brand image, and cultivating characteristic tourism cities and towns. The resource development of other regions needs to be improved. The industrial belt should focus on the Kashi folk culture tourism area and Aksu World Heritage Tourism Area. It is necessary to build the cultural and ethnic tourism destination along the Silk Road in southern Xinjiang with the view of high-quality tourist attractions, characteristic ethnic culture tourism towns (villages), tourism commodity production and marketing base, transnational tourism cooperation zone, tourism distribution service system, etc.

(5) Urumqi international tourism distribution center only includes Urumqi, and its tourism performance, tourism basic supporting capacity and tourism resource utilization are good. However, due to a large number of local restaurants and the relative lack of online attention, its market attention is low. It leads to the extremely low attention of restaurants. As Urumqi is the hub of Xinjiang tourism distribution center, its status and image are very important to Xinjiang tourism. We should give full attention to its core linkage of the spindle role and link with other industrial belts to create a market image. Hence, the overall attention of Xinjiang will be improved.

At the same time, the differences between the industrial belts cannot be ignored. There are significant differences in the use of tourism resources in all industrial belts, and they should therefore coordinate their cooperation and competition. It is necessary for each to take full advantage of their tourism resources and keep their development orientation. Meanwhile, strengthening the interconnection between the industrial belts is essential as is investing in the core hub role of Urumqi International Tourism Distribution Center. Furthermore, it's important to build the cultural and ethnic tourism destination along the Silk Road in southern Xinjiang. The construction of the Tianshan corridor World Heritage Site tourism and the ecotourism industrial belt in the northern margin of Junggar should also be improved.

\section{Conclusions}

This paper studied the development of Xinjiang tourism industrial belts and subsequently raised tactics for tourism future planning and sustainable development. Under the guidance of the balanced scorecard concept, an evaluation system for Xinjiang tourism development was established from four dimensions: tourism performance, resource utilization, basic supporting capacity and market attention. Then, by means of AHP, the performance evaluation of 14 Prefectures' tourism development was conducted. Finally, the difference of four tourism industrial belts and the corresponding impact were discussed by Theil index and Entropy method.

The empirical results in this article showed that the intra-industrial belt difference was greater than the inter-industrial belt difference for various dimensions. Moreover, 
this research revealed a differentiation phenomenon of tourism industrial belt, and it's noteworthy that the difference is the most significant in resource utilization. In this sense, this paper provided positive tactics and suggestions for the development of industrial belt.

Author Contributions: Conceptualization, X.M.; validation, X.Q.; formal analysis, X.Q.; resources, X.Q.; writing-original draft preparation, Y.X.; writing-review and editing, X.Q.; supervision, X.X.; project administration, X.M.; funding acquisition, X.X. and X.M. All authors have read and agreed to the published version of the manuscript.

Funding: This work is supported by the Ministry of Culture and Tourism of the People's Republic of China (grant No. MCT2020XZ09) and the Science and Technology Department of Xinjiang Uygur Autonomous Region (grant No. XJEDU2019SY006).

Institutional Review Board Statement: Not applicable.

Informed Consent Statement: Not applicable.

Data Availability Statement: Not applicable.

Acknowledgments: We would like to thank the anonymous reviewers for their constructive feedback and detailed suggestions.

Conflicts of Interest: The authors declare no conflict of interest.

\section{References}

1. Chan, G.; Tang, I.; Zhang, M. Perceptions of Residents in Xinjiang, Urumqi towards Tourism Development through China's Belt and Road Initiative. J. Manag. Sustain. 2018, 8, 59-74. [CrossRef]

2. Fayard, G. Sun, Sand and Submachine Guns: Tourism in a Militarized Xinjiang, China. China Q. 2021, 1-23. [CrossRef]

3. Wu, W.; Shen, H.; Ji, C.; Liu, H. Study on evaluation index system of water conservancy ecotourism development potential. Manag. World 2012, 184-185.

4. Wu, W.; Liu, Y.; Zhang, C. The early warning management of Ice Snow Tourism Resources based on the carrying capacity. Chin. J. Manag. Sci. 2014, 22, 659-665.

5. Li, T.; Cai, B.; Tao, Z. Research on the leisure agriculture tourism based on environmental health evaluation. Geogr. Res. 2016, 35, 2125-2138.

6. Huang, S.; Li, Y.; Dai, P. Evaluation of tourism competitiveness of Chinese Smart Tourism City. Acta Geogr. Sin. 2017, 72, 242-255.

7. Butowski, L. An integrated AHP and PROMETHEE approach to the evaluation of the attractiveness of European maritime areas for sailing tourism. Morav. Geogr. Rep. 2018, 26, 135-148. [CrossRef]

8. Ling, G. Potential and performance evaluation of leisure agriculture in Romote Mountainous Areas in Jiangxi Province. Chin. J. Agric. Resour. Reg. Plan. 2019, 40, 303-308.

9. Gao, W.; Cao, H.; Wang, Y. A research on tourism performance and driving forces of Islands: A Case Study of 12 Islands Counties (Districts) in China. Math. Pract. Theory 2020, 50, 264-273.

10. Grilli, G.; Tyllianakis, E.; Luisetti, T.; Ferrini, S.; Turner, R.K. Prospective tourist preferences for sustainable tourism development in small island developing states. Tour. Manag. 2020, 82, 1-10. [CrossRef]

11. Liu, H.; Zhang, J. Construction of evaluation index system for sustainable development of rural tourism-Taking Longnan city as an example. Mod. Agric. 2020, 8, 106-109.

12. Kaplan, R.S.; Norton, D.P. The balanced scorecard-measures that drive performance. Harv. Bus. Rev. 1992, 70, 71-79. [PubMed]

13. Ma, N.; Hou, Q. Research on the performance evaluation system of fiscal funds on science and technology based on Balancedscorecard Method. China Soft Sci. 2016, 10, 184-192.

14. Liang, M.; Liu, W. A research on the performance evaluation of corporate major disaster donations based on Balanced Scorecard. Sci. Res. Manag. 2018, 39, 31-36.

15. Zhou, C. On evaluation index system and construction of urban tourism development quality based BSC method-A case study of 21 cities in Guangdong province. J. Southwest China Norm. Univ. 2019, 44, 69-74.

16. Wang, Y.; Shen, S.; Sotiriadis, M.; Zhang, L. Suggesting a framework for performance evaluation of tourist attractions: A balance score approach. Sustainability 2020, 12, 6220. [CrossRef]

17. Meng, Y.; Wu, N.; Li, Y.; Zhu, C.; Kong, L. BIM impact assessment of landscape architecture design. J. Phys. Conf. Ser. 2020, 1533, 1-6. [CrossRef]

18. Ma, D.; Wang, L. Countermeasures and suggestions of building leisure tourism industrial belt around Beijing and Tianjin. Commer. Res. 2009, 7, 151-153.

19. Gao, H.; Chen, S. The main problems and countermeasures of the construction of leisure tourism industrial belt around Beijing and Tianjin. Hebei Acad. J. 2009, 29, 235-240.

20. Weng, G.; Yang, X. Urban competition-collaboration of the leisure tourism industry belt around Beijing\& Tianjin in Hebei province. Hum. Geogr. 2012, 27, 143-146. 
21. Feng, X. An Optimization Study on Scenic Spatial Structure of the Junggar Tourism Industrial Belt; Shihezi University: Shihezi, China, 2014.

22. Gao, F. Decomposition of "Space" and "Power" dual factors of China's regional economic gap. Econ. Sci. 2012, 5, 5-17.

23. Chen, M.; Zhang, S. Regional economic imbalance in China and the influence factors: Based on night-time light data. Stat. Res. 2020, 37, 40-54

24. Zhang, L.; Wen, T. Research on the spatial-temporal characteristics and dynamic evolution of real economy growth in China. J. Quant. Tech. Econ. 2020, 37, 47-66.

25. Yan, J.; Cui, R. Study on spatial-temporal differentiation and convergence of tourism economy in the Huaihe river eco-economic belt. Areal Res. Dev. 2020, 39, 91-97. 